\title{
A Multilevel Model of Information Technology Value
}

Matt Wimble, Harminder Singh, and Brandis Phillips

\section{QUERY SHEET}

This page lists questions we have about your paper. The numbers displayed at left can be found in the text of the paper for reference. In addition, please review your paper as a whole for correctness.

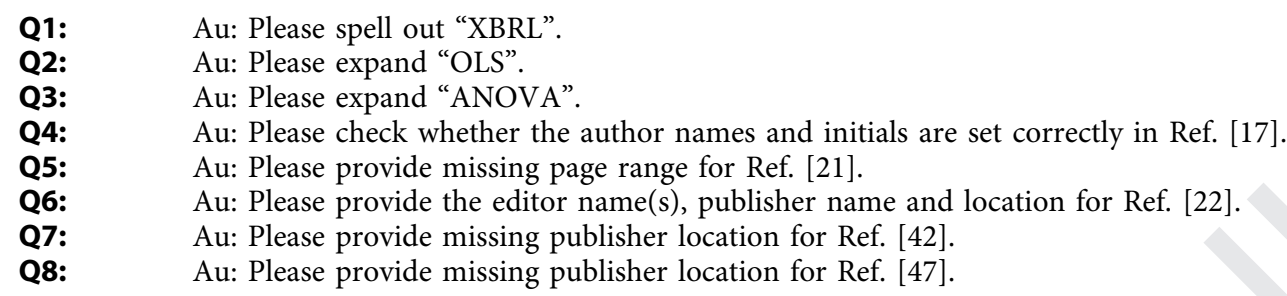

\section{TABLE OF CONTENTS LISTING}

The table of contents for the journal will list your paper exactly as it appears below: 


\title{
A Multilevel Model of Information Technology Value
}

\author{
Matt Wimble ${ }^{a}$, Harminder Singh ${ }^{b}$, and Brandis Phillips ${ }^{c}$ \\ aUniversity of Michigan-Dearborn, Dearborn, MI, USA; ${ }^{b}$ Auckland University of Technology, Auckland, New Zealand; ${ }^{c}$ North Carolina A\&T State \\ University, Greensboro, NC, USA
}

ABSTRACT

Traditionally, firms that dominate their industries perform better when their markets are growing. This is because their large size makes it easier for them to achieve economies of scale. We present empirical evidence that the impact of information technology (IT) on the firm performance is the opposite: firms with less market power enjoy greater benefits in a growing market. This study draws on the IT value literature to examine how industry and firm attributes jointly affect firms' returns on their IT investments. To that end, we develop cross-level hypotheses to examine how the economic value of IT to firms is influenced by industry growth and firm size. By using a hierarchical linear model to test the industryfirm interactions, we are able to control for violations of statistical assumptions that are likely to bias cross-level estimates obtained using conventional statistical methods. The implications of these findings for research and practice are examined.

\section{KEYWORDS}

Business value of information technology; industry effects; multilevel modeling; market share; industry growth

\section{Introduction}

Information technology (IT) has become an important component of doing business for many firms and now represents the single largest category of capital investment in the United States [44]. The impact of this spending on various measures of firm performance, such as labor productivity, profitability, and market valuation, has been studied by many researchers (e.g. Jorgenson [25], Triplett and Bosworth [47], Bharadwaj et al., [10], Brynjolfsson and Hitt, [12], Hitt and Brynjolfsson, [23], Morrison, [34], Anderson, Banker and Ravindran, [2], Aral \& Weill, [5], Stiroh, [44]; Pilat [36]). The majority of these studies have also examined how firm-specific attributes, such as complementary organizational practices and IT cap-

30 abilities [7, 8, 35, 37], affect IT value. The aforementioned research provides an overview of the business value of the IT literature that serves as a basis for the following literature review.

\section{Literature Review}

35 In contrast, the impact of industry attributes on the value of IT to firms has been largely under-explored. In their review of IT value research, Melville et al., [32] ask: "What is the role of industry characteristics in shaping IT business value?" This relationship is worth studying as it reflects underlying differ-

40 ences in how similar inputs are used across different industries. Anecdotal evidence and practitioner studies indicate that industries differ to the extent in which they adopt and use IT, as well as in the effectiveness with which they leverage IT functionalities and capabilities [21,22]. These distinct char- productivity [9]. This field of research has a corollary in strategic management, where studies have found that a firm's performance is significantly affected by its membership in a particular industry $[11,14,30]$.

A separate, but related, issue is how the impact of industry characteristics should be assessed. Prior research has handled industry heterogeneity by using (a) industry dummies [4] or (b) industry attributes, such as capital intensity, concentration, and competitiveness $[15,31]$, as controls. While being reasonable proxies, these methods are a limited way of understanding the relationship between industries and firm-level IT value. This is because, the nested structure of firms within industries, meaning that firms in a particular industry tend to be more similar to other firms in the same industry, compared to other firms in different industries. Using industry dummies or attributes leads to ecological bias $[40,46]$, where inferences about individual firms are made from studies of groups (industries). To prevent this, studies of IT value should separate out the variance in the data due to the membership of a particular industry from firm-specific variance. Not doing so leads to the underlying relationships between industry attributes and firm-level IT business value being misconstrued, because many of the effects observed at the firm-level may in fact be the result of industry-level factors which affect all firms in an industry and are not within a manager's control.

This study aims to address these gaps in our knowledge by focusing on the combined impact of industry growth and firm size on the firm-level IT value. While large firms usually possess slack resources and economies of scale to take advantage of technological advances, i.e. obtain more value from their IT investments, this may not hold true in fast-growing industries. In fast-growing industries, technological advances tend to be more disruptive, while in established industries, IT on performance measures, such as industry output and 
technological change tends to be more incremental [18]. Large firms are inherently designed to use economies of scale to exploit incremental innovation as predicted by a "classical economics" view [24]. In "Schumpeterian Competition", new industries and markets are created [42]. The existing firms are at a disadvantage because they view new products as a source of unneeded risk which could cannibalize the existing sales. In such well-established industries, the existing (legacy) IT base of large firms would increase their switching costs of adopting new technologies. Hence, smaller firms would be able to

90 adopt newer IT much more easily in growing industries, and thus, obtain more value from their IT investments. The research questions are:

How does IT provide greater value to firms in high growth industries?

If so, how does this impact differ across firms with varying levels of market power?

This study contributes in three ways. First, two research streams on IT value (industry-level and firm-level) are simultaneously considered and integrated. This is an important addition to the IT value literature and should improve our understanding of the impact of IT investments on firm performance. Second, specific cross-level explanations for IT value are put forward. Managers often use industry norms as a basis for their decisions via the practice of benchmarking, but have to adapt those norms to the circumstances of their specific firm. The cross-level explanations provided here can potentially contribute to explaining additional variance in firm IT investment behavior better. Third, the cross-level analysis of IT value is carried out using hierarchical linear modeling (HLM) [38], an analytic method that is expressly designed to estimate models with nested data structures. Thus, ecological bias is removed as a potential explanation for findings on IT value. HLM allows the variance found in the dependent variable to be partitioned across multiple levels 115 of analysis, while taking into account differences in sample size and variance among different elements grouped within a given hierarchical level.
We next present the details of our model and hypotheses, followed by the description of the data, the analysis procedures, and the results. The paper concludes after a discussion of the implications of the results.

\section{Hypothesis Development and Research Model}

Systems' theory posits that focusing on either firm or industry attributes alone will not be as valuable as examining their interactive effect. This is because managers make decisions in particular contexts, indicating that the attributes of each level (firm and industry) are interdependent [43]. Industry matters in two broad ways for explaining how the impact of IT differs among industries: (a) it sets out the social norms as to what IT to invest in and (b) the various industry attributes moderate the impact of firm-level characteristics on IT value. Thus, IT-related decisions made by firms' managers reflect in some fashion the social and cognitive influences of the institutional settings in which they are located [17]. For example, decisions to adopt collaborative technologies, such as RosettaNet, Wi-Fi, electronic bill payment (EBPP), and XBRL, are affected by the level of network externalities related to them [28].

Beyond industry practices and norms, researchers should focus on identifying the particular mechanisms through which IT provides a payoff by integrating industry and firm attributes. This requires going beyond traditional explanations of IT's impact, such as capital deepening (for labor-intensive industries) and technical progress (for the computer-producing and durable goods sectors) [19]. In that light, this study examines how industry growth influences the impact of a firm's market-share on the value it receives from its IT investments (Figure 1).

In growing industries, a firm's speed of response is important and developing these "sense and respond" capabilities [41] will help enhance its agility. IT is often used to enable such capabilities, including environment scanning, customer recruitment, and taking advantage of rapid market changes. In contrast, IT's impact in slow-growth industries is often more on cost containment than revenue enhancement. Thus, the first hypothesis is that:

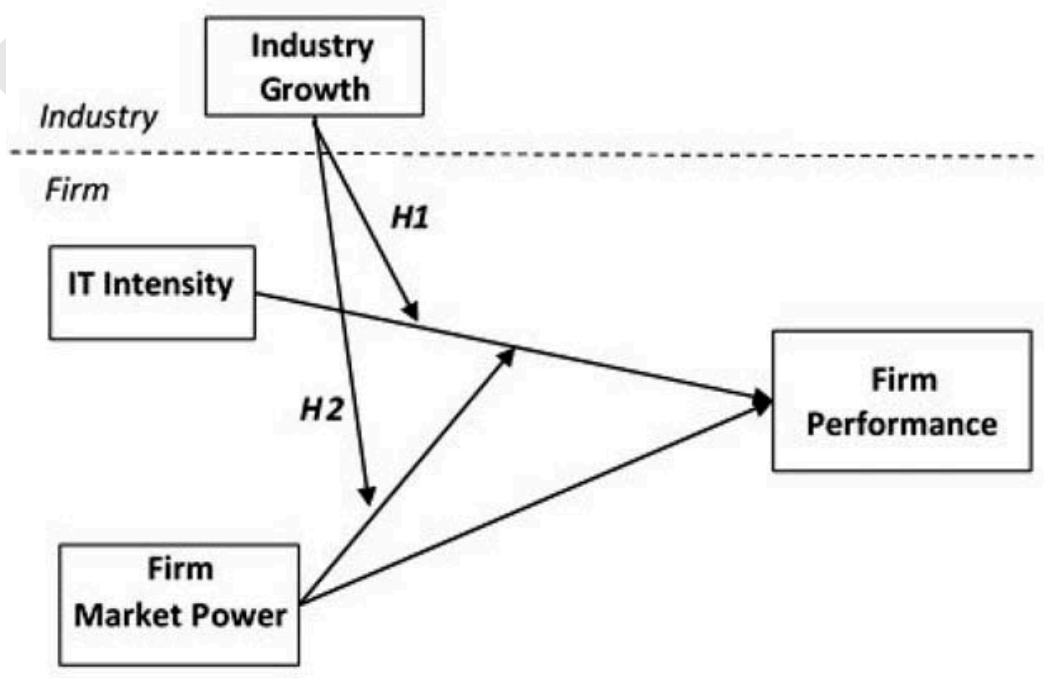

Figure 1. Research model. 
$155 \mathrm{H1}$ : Industry growth positively moderates the relationship between IT intensity and firm performance.

A firm's market-share indicates its market power and provides economies of scale benefits [13], and has been found to affect its performance. These scale benefits apply to obtaining benefits from IT investments, too, as firms with a larger market-share possess the necessary slack resources to undertake corporate-level strategic IT actions, as well as being able to spread out the costs of these investments over a larger scale

165 of production. Thus, ceteris paribus, we expect firms with a high market-share to obtain more value from their IT investments.

However, this relationship between market share and performance may be modified by the level of industry growth.

170 Industries with higher growth rates have lower levels of competitive rivalry, since new firms can take advantage of the increasing market size without having to compete with the existing firms. The expanding market may encourage older firms, i.e. those with a larger share of the market, not to invest 175 in new technology, as they are doing well without such investments. The lower level of rivalry makes it easier for new firms to enter the market. Compared to the existing firms, new firms will be more willing to invest in IT, so that they will be able to ramp up their economies of scale to support 180 increased transaction volumes [26]. In addition, newer firms will not be faced with the switching costs associated with transitions out of less efficient legacy technology, making them more likely to have more up-to-date technology [6]. These switching costs comprise the costs of learning the

185 knowledge needed to utilize the new technology, and the costs of redesigning work processes to take advantage of the new technology [6]. These switching costs make the existing firms less agile, compared to new firms, as they persist in using their standard operating procedures and routines. Thus, the second hypothesis is:

$\mathrm{H} 2:$ The moderating impact of industry growth on the relationship between IT-intensity and firm performance is stronger for firms with lower market power.

195 As our focus is on the interaction of industry-level effects, hypotheses at the firm-level are not specifically hypothesized.

\section{Methodology}

We employ HLM, [38] as it is recommended for analyzing nested data. HLM is useful for nested data because it helps overcome: (a) aggregation bias, when a variable has different meanings at different levels, (b) misestimated errors, which occur because observations at different levels are not independent, and (c) heterogeneity of regression, where relationships between level 1 units differ across level 2 units [33]. In our 205 context, firms (level 1 units, in HLM terminology) are nested within industries (level 2 units); this implies that within-industry (i.e. across-firm) variation in performance must take into account the industry membership. The dependent variable at level 1 (the individual level) serves as the moderator at level 2 on the other hand, assumes that the effect of IT on firm performance and the mean level of performance are identical across industries. HLM provides an estimate of the variance in firm performance connected with between-industry differences in attributes, such as concentration and capital intensity. This is not possible when industry summary statistics of these attributes are used as outcomes in standard ANOVA or regression models as controls.

\section{Data}

Data collected between 1998 and 2004 on the IT investments of 1,413 firms that are part of 290 industries is used to test our hypotheses. Both IT investment and accounting data were collected. Firm-level data on IT spending is difficult to obtain, since firms do not have a separate line-item on their balance sheet for IT expenditure. Thus, we used data from a survey of IT executives carried out by Information Week that collects details on IT budgets, the number of IT employees, and other IT-related information. The Information Week data have been used extensively in other studies $[16,26,29]$. The accounting data are from Compustat. Industry-level data were obtained from the Bureau of Economic Analysis (BEA) and the Bureau of Labor Studies (BLS). While some recent studies (e.g. Tambe and Hitt [45]; Dewan and Ren, [20]) have used data that cover a much longer time-span than this study, the key issue regarding the appropriateness of a dataset is whether it allows you to test the research question regardless of time frame. Thus, the dataset during the time period selected enables us to appropriately answer the research questions.

The variables are operationalized as follows. Firm market power, a proxy for firm size, was measured as firm market share, which is the ratio of its sales to industry sales. IT investment was operationalized as IT intensity, and measured as the ratio of a firm's IT expenses to its revenue, similar to prior studies [33]. Industry growth was measured as the average growth of industry revenues over the preceding three years. Return on assets (ROA) was used as the measure of firm performance. Macro-economic fluctuations were controlled for by including a dummy variable for each of the years in which data were collected.

\section{Analysis}

The variables of interest in this study are at both the firm level (performance, size and IT investment) and the industry level (industry growth). Since traditional techniques such as regression are inappropriate for testing cross-level models [38], we use HLM to test our hypotheses [3, 27, 33]. We use full maximum likelihood (ML) and an empirical Bayes procedure to estimate the model in HLM v.6.05a [39]. ML estimation helps to obtain efficient estimates for unbalanced panels [38], indicative of the dataset in this study, where the same firms do not appear in all of the years.

The model was estimated in an incremental approach, which allows model testing. First, a fully unconditional model was tested where there were no covariates at either level (Model 1). This helped us evaluate whether sufficient variation existed in firm performance. Next, we estimate a random coefficient 
model, where we add firm-level covariates (Model 2). The significance of the random effects can be assessed by comparing the deviance $(-2 \log$ likelihood criterion) between the two nested models, using a $\chi^{2}$ distribution. The degrees of freedom for this test will be the difference in the number of parameters between the two models.

In the third step, we include industry-level covariates (Model 3 ), which means that we allow slopes and intercepts to vary across industries. Thus, in this level 2 model, the intercepts and slopes of the level 1 model are estimated using industry-level covariates. Partitioning the variance in this way allowed the computation of the intra-class correlation (ICC), which is a measure of the relatedness or dependence of nested data. ICC is equal to $\sigma^{2} / \sigma^{2}+\tau$, where $\sigma^{2}$ is between-industry variation and $\tau$ is within-industry variation. It should be noted that this paper is focused on estimating the impact of industry growth on a) the IT-firm performance relationship, and b) the moderating effect of firm market-share on the IT-firm performance relationship. Formally, the model is as follows.

Firm-level (within-industry) model:

$$
\begin{aligned}
Y_{i j}= & B 0_{i j}+B 1_{i j} *\left(M_{K T S H R}\right)+B 2_{i j} *\left(\operatorname{ITMKTSHR}_{i j}\right) \\
& +B 3_{i j} *\left(I T_{i j}\right)+R,
\end{aligned}
$$

where $Y$ is the return on assets (ROA) of the ith firm in industry $j$; $M K T S H R_{i j}$ and $I T_{i j}$ denote the market share and IT intensity, respectively, of the $i$ th firm in industry $j$; $290 I T M K T S H R_{i j}$ is an interaction term to test; $B 0_{i j}$ is the conditional mean performance of all firms in industry $j ; B 1-3_{i j}$ are the conditional effects (the slopes) of market share, the interaction between market share and IT intensity, and IT intensity, respectively, for firms in industry $j$.

295 Industry-level (between-industry) model:

$$
\begin{gathered}
B 0=G 00+G 01 *(\text { YEAR })+G 02 *(\text { GROWTH })+U 0, \\
B 1=G 10+G 11 *(\text { GROWTH }), \\
B 2=G 20+G 21 *(\text { GROWTH }), \\
B 3=G 30+G 31 *(\text { GROWTH }),
\end{gathered}
$$

300 where

G00 is the mean ROA of firms in industry $j$;

G10-G30 are the mean effects of market share, the interaction between market share and IT intensity, and IT intensity, respectively, for firms in industry $j$;

G11-G31 are the conditional effects (the slopes) of the industry growth rate on the impact of market share, the interaction between market share and IT intensity, and IT intensity, respectively, of firms in industry $j$.

\section{Results}

Tables 1 and 2 depict the correlation matrix for the variables. Note that the correlation between industry growth (GROWTH) and year (YEAR) is different across levels: it is negative at the firm level and positive at the industry level. This variance in the relationship at different ecological levels is a further indication that HLM is an appropriate methodology for this dataset. As is common in multilevel studies, ecological factors such as industry growth was centered at its grand mean and firm-level variables were centered at their group means. This implies that the intercept at the firm-level represents the mean ROA for a firm at its average level of IT intensity and market-share across the years, and the average level of industry growth across the entire sample.

Table 3 lists the results. The results of the null model (Model 1) point to significant variance in ROA $\left(\chi^{2}=176.025\right.$, $d f=144, p=0.036$ ), indicating the need for further analysis. The largest percentage of variation in firm performance lies within industries (93.25\%), while a smaller proportion lies across industries $(6.75 \%)$. Here, while the industry factors have significant interaction with firm effects, much of difference in result is due to differences between individual firms. Model 2 shows that a firm's market share significantly affects its ROA, which is consistent with prior research. However, a firm's IT intensity and the interaction of its IT intensity with its market share do not affect its ROA. Our hypotheses are tested in Model 3, which includes industry growth. Hypothesis 1 , which argues that IT has a stronger (weaker) impact on firm performance when firms are located within growing (shrinking) industries, is supported $(\mathrm{G} 31=6.671, p<0.05)$. Hypothesis 2 posits that, within growing industries, firms with a smaller market share obtain more value from their IT investments. The interaction between industry growth and IT intensity (G31) changes from positive to negative when market share is used to expand that interaction term (G21). Thus, Hypothesis 2 is also supported (G21 $=-109.406$, $p<0.05$ ). In sum, the results suggest that IT is an enabler in growing industries especially for smaller firms that have not reached large economies of scale. See Table 4 below for a summary of the hypotheses.

\section{Discussion}

\section{Limitations}

The results of this study should be seen in light of its limitations. First, the Information Week data are self-reported, so they may be biased to enhance the reputation of the informant. Second, other variables that have been shown to be significant covariates of IT value could be added as further controls in the analysis. Third, accounting-based measures of

Table 1. Correlations of firm-level variables $(n=1413)$.

\begin{tabular}{llcccc}
\hline & ROA & MKTSHR & IT & ITMKSHR & Growth \\
\hline ROA & 1 & & & & \\
MKTSHR & 0.0662966 & 1 & 1 & & \\
IT & 0.0154741 & -0.01492 & 0.5685755 & & \\
ITMKTSHR & 0.0491429 & 0.5039213 & -0.086709 & 0.0137216 & 1 \\
Growth & 0.1767748 & 0.1104163 & -0.062207 & -0.016017 & -0.02976 \\
Year & -0.072826 & 0.0517468 & & 1 \\
\hline
\end{tabular}


Table 2. Correlation of industry-level variables $(n=290)$.

\begin{tabular}{llc}
\hline & Growth & Year \\
\hline Growth & 1 & \\
Year & 0.0832809 & 1 \\
\hline
\end{tabular}

Table 3. Model results.

\begin{tabular}{|c|c|c|c|}
\hline Variable & Model 1 & Model 2 & Model 3 \\
\hline Intercept (G00) & $0.0456^{* *}(0.006)$ & $0.0364 * *(0.008)$ & $0.044^{* *}(0.009)$ \\
\hline Year (G01) & - & - & $-0.004^{*}(0.002)$ \\
\hline Growth (G02) & - & - & $0.143(0.104)$ \\
\hline Firm-level effects & - & & \\
\hline $\begin{array}{l}\text { Market Share } \\
\quad(\mathrm{G} 10)\end{array}$ & - & $0.1620^{* *}(0.051)$ & $0.229^{* *}(0.075)$ \\
\hline $\begin{array}{l}\text { Market Share *IT } \\
\text { Intensity } \\
\text { (G20) }\end{array}$ & - & $0.2454(2.293)$ & $-1.749(2.154)$ \\
\hline IT Intensity (G30) & - & $0.114(0.216)$ & $-0.205(0.212)$ \\
\hline Cross-level effects & & & \\
\hline $\begin{array}{l}\text { Growth * Market } \\
\text { Share (G11) }\end{array}$ & - & - & $0.633(0.465)$ \\
\hline $\begin{array}{l}\text { Growth * Market } \\
\text { Share } \\
\text { * IT Intensity } \\
\text { (G21) }\end{array}$ & - & - & $-109.406 *(48.65)$ \\
\hline $\begin{array}{l}\text { Growth * IT } \\
\text { Intensity } \\
\text { (G31) }\end{array}$ & - & - & $6.671 *(3.071)$ \\
\hline $\begin{array}{l}\text { Deviance } \\
\qquad(-2 \text { log } \\
\text { likelihood })\end{array}$ & -949.1814 & -955.3922 & -977.9395 \\
\hline$\sigma^{2}$ & 0.01617 & 0.01605 & 0.01313 \\
\hline$T$ & 0.00108 & 0.00118 & 0.00095 \\
\hline \multicolumn{4}{|l|}{$\begin{array}{l}\text { Variance } \\
\quad \text { decomposition }\end{array}$} \\
\hline $\begin{array}{l}\text { Across Firms } \\
\quad\left(\mathrm{ICC}=\sigma^{2} / \sigma^{2}+\right. \\
\quad \tau)\end{array}$ & $93.74 \%$ & $93.15 \%$ & $93.25 \%$ \\
\hline $\begin{array}{l}\text { Across Industries } \\
(1-I C C)\end{array}$ & $6.26 \%$ & $6.85 \%$ & $6.75 \%$ \\
\hline
\end{tabular}

Table 4. Hypotheses results.

\begin{tabular}{lc}
\hline Hypothesis & Support \\
\hline H1: Industry growth positively moderates the relationship between & YES \\
IT intensity and firm performance & \\
H2: The moderating impact of industry growth on the relationship & YES \\
between IT-intensity and firm performance is stronger for firms & \\
with lower market power. & \\
\hline
\end{tabular}

firm performance, such as ROA, are prone to managerial manipulation. Thus, the relationships shown here should be tested against other measures of firm performance, such as Tobin's Q. Finally, a generic "IT intensity" measure was used here. In place of this gross measure, future studies should utilize more fine-grained measures of IT, as the relationships found here may differ across different types of IT investments. Nevertheless, the research avoids common methods bias by sourcing data from Compustat, BLS, BEA, and Information Week. Furthermore, using HLM allows the examination of both firm- and industry-level effects simultaneously to provide a more contextualized understanding of the impact of IT investments.

\section{Implications}

This study is in accordance with the call for IS researchers to generate "macro" theories of IT-enabled transformations in different contexts [1]. Identifying some of the primary mechanisms through which IT's impact varies across different contexts is an important task for a number of reasons. For one, this study will improve researchers' ability to clarify the IT productivity conundrum that began with a lack of value in the 1980s, to findings suggesting IT has been found to have "too high" returns now. Perhaps, the use of multilevel models will help separate out the various impacts IT has had in different contexts. Second, it may help improve the targeting of scarce corporate resources when making IT-related investments. Being aware of the pathways through which firms obtain positive benefits from their IT investments should improve managers' IT investment decisions.

The results of this study reinforce the argument that IT investments and their impact are contextually determined. By examining the interaction of only three variables, we found some interesting relationships, and it is probable that other, similarly-intriguing relationships will be found when other variables are studied. Since IT has a higher impact on the performance of newer firms in growing industries, it is possible that the often-reported phenomenon of time lags in the realization of IT value may be found only among certain categories of firms. These should include those with substantial legacy investments, which have increased their switching costs. How should the existing firms in growing industries resolve this challenge? If they do not, they risk the new entrants to their industry accruing their rents. Since the ultimate goal is firm performance, one option would be for firms to regularly re-evaluate their IT portfolios in terms of their switching costs. IT assets with lower switching costs should be preferred, as they will help maintain a firm's agility. As further research on other cross-level interactions is carried out, it behooves researchers to share their findings with firms so as to lower the proportion of unnecessary IT investments and increase the value they obtain from those that have.

\section{Conclusions}

This research is the first to examine how the level of industry growth influences the impact of IT on firm performance, while controlling for aggregation effects and cross-industry variation in IT use. There are two key contributions of this research:

(1) Assessing the role of industry-level characteristics, such as growth, in affecting the impact of IT on firm performance; and

(2) Presenting a methodology whereby the contingencies that impact the value firms obtain from IT can be assessed.

Given the debate in IS research regarding the impacts of IT, the questions that have gained significance are similar to "when does IT matter?" and "how does IT matter?" This study's results imply that while measuring the impacts of information systems, 
it is essential to factor in macro-level industry factors, as they influence the impact of IT. Future work on IT value should not neglect the nested nature of firms by using methods that do not take into account multilevel influences. Doing so could lead to incomplete or even misleading results, which could have impacts on the decisions managers make.

Further research could extend this study in two ways. First, additional industry-level variables that are known to influence 430 the impact of IT on firm performance, such as concentration, dynamism, uncertainty, the level of regulation, and the role of IT in the industry (i.e. automate, informate up or down, transform), could be used to uncover additional mechanisms through which firms obtain a payoff from their IT investments.

435 Second, a third level of analysis could incorporate the wider macro-economic environment firms operate in. Here, the impact of covariates, such as national income (GDP), the inflation rate, and educational level, could be used to evaluate whether and how they impact the effect of IT on firm performance. Given the fluctuations in economic growth and inflation over the past decades, it is worth examining if these macroeconomic variables should be taken into account while establishing the criteria for evaluating IT impact. The ensuing three-level interactions would 445 help identify how firms should harness their IT assets according to conditions in their industry and the wider macro-economy. More importantly, they would lay the base for developing a new process theory of IT value that incorporates the impact of industry- and country-wide attributes. This could be potentially useful in helping improve our explanation of the impacts of IT. By considering contingencies at multiple levels, researchers should be able to help manager's improve their IT investment decisions.

\section{References}

[1] Agarwal R, Lucas H. 2005. The information systems identity crisis: Focusing on high-visibility and high-impact research. MIS Q. 29(3):381-398.

[2] Anderson MC, Banker RD, Ravindran S. 2006. Value implications of investments in information technology. Manage Sci. 52 (9):1359-1376.

[3] Ang S, Slaughter S, Ng KY. 2002. Human capital and institutional determinants of information technology compensation: Modeling multilevel and cross-level interactions. Manage Sci. 48(11):359-1376.

[4] Aral S, Brynjolfsson E, Wu DJ. 2006. Which came first, it or productivity? The virtuous cycle of investment and use in enterprise systems. In: International Conference on Information Systems, Milwaukee.

[5] Aral S, Weill P. 2007. Assets, organizational capabilities \& firm performance: How resource allocations and organizational differences explain performance variation. Organ Sci. 18 (5):1-18.

[6] Atkeson A, Kehoe P. 2007. Modeling the transition to a new economy: Lessons from two technological revolutions. Am Econ Rev. 97(1):64-88.

[7] Banker RD, Bardhan IR, Chang H, Lin S. 2006. Plant information systems, manufacturing capabilities, and plant performance. MIS Q. 30(2):315-337.

[8] Barua A, Konana P, Whinston AB, Yin F. 2004. An empirical

9] Basu S, Fernald J. 2006. Information and communications technology as a general-purpose technology: Evidence from U.S. investigation of net-enabled business value. MIS Q. 28(4):585-620. industry data. In Working Paper Series, Federal Reserve Bank of San Francisco.

[10] Bharadwaj AS, Bharadwaj SG, Konsynski BR. 1999. Information technology effects on firm performance as measured by Tobin's q. Manage Sci. 45(7):1008-1024.

[11] Brush TH, Bromiley P, Hendrickx M. 1999. The relative influence of industry and corporation on business segment performance: An alternative estimate Strategic Manage J. 20:519-547.

[12] Brynjolfsson E, Hitt LM. 1996. Paradox lost? Firm-level evidence on the returns to information systems spending. Manage Sci. 42 (4):541-558.

[13] Capon N, Farley JU, Hoenig S. 1990. Determinants of financial performance: A meta-analysis. Manage Sci. 36(10):1143-1159.

[14] Chang SJ, Singh H. 2000. Corporate and industry effects on business unit competitive position. Strategic Manage J. 21:739-752.

[15] Chari MD, Devaraj S, David P. 2007. International diversification and firm performance: Role of information technology investments. J World Bus. 42:184-197.

[16] - 2008. The impact of information technology investments and diversification strategies on firm performance. Manage Sci. 54 (1):224-234.

[17] Chiasson MW, Davidson E. 2007. Industry level supplier-driven IT spillovers. MIS Q. 29(4):2-16.

[18] Christensen C. 2013. The innovator's dilemma: When new technologies cause great firms to fail. ed, Harvard Business Review Press.

[19] Dedrick J, Gurbaxani V, Kraemer K. 2003. Information technology and economic performance: A critical review of the empirical evidence. ACM Comput Surv. 35(1):1-28.

[20] Dewan S, Ren F. 2011. Information technology and firm boundaries: Impact on firm risk and return performance. Inf Syst Res. 22 (2):369-388,415,417.

[21] Farrell D. 2003. The real new economy. Harv Bus Rev. 81(10).

[22] Forman C, Goldfarb A, Greenstein S. 2003. Which industries use the Internet? In Organizing the New Industrial Economy.

[23] Hitt L, 1996. Brynjolfsson E. Productivity, business profitability and consumer surplus: Three different measures of information technology value. MIS Q. 20(2):121-142.

[24] Johnson MWChristensen CM, Kagermann H. 2008. Reinventing your business model. Harv Bus Rev. 86(12):57-68.

[25] Jorgenson DW. 2001. Information technology and the US economy. Am Econ Rev. 1-32.

[26] Kobelsky K, Richardson VJ, Smith RE, Zmud RW. 2008. Determinants and consequences of firm information technology budgets. Accounting Rev. 83(4):957-995.

[27] Levina N, Xin M. 2007. Comparing IT workers' compensation across country contexts: Demographic, human capital, and institutional factors. Inf Syst Res. 18(2):193-210.

[28] Li X, Kauffman RJ, Yu F, Zhang Y. 2014. Externalities, incentives and strategic complementarities: Understanding herd behavior in IT adoption. Inf Syst E-Bus Manage. 12(3):443-464.

[29] Liu Y, Ravichandran T. 2008. A comprehensive investigation on the relationship between information technology investments and firm diversification. Inf Technol Manage. 9(3):169-180.

[30] McGahan AM, Porter ME. 2003. The emergence and sustainability of abnormal profits. Strategic Organ 1(1):79-108.

[31] Melville N, Gurbaxani V, Kraemer K. 2007. The productivity impact of information technology across competitive regimes: The role of industry concentration and dynamism. Decis Support Syst. 43:229-242.

[32] Melville N, Kraemer K, Gurbaxani V. 2004. Information technology and organizational performance: An integrative model of IT business value. MIS Q. 28(2):283-322.

[33] Mithas S, Ramasubbu N, Krishnan MS, Fornell C. 2006-2007 Designing web sites for customer loyalty across business domains: A multilevel analysis. J Manage Inf Syst. 23(3):97-127.

[34] Morrison CJ. 1997. Assessing the productivity of information technology equipment in US manufacturing industries. Rev Econ Stat. 79(3):471-481. 
[35] Pavlou PA, El Sawy OA. 2006. From IT leveraging competence to competitive advantage in turbulent environments: The case of new product development. Inf Syst Res. 17(3):198-227.

[36] Pilat D. 2004. ICT and economic growth: Evidence from OECD Countries, industries, and firms, OECD.

[37] Rai A, Patnayakuni R, Nainika S. 2006. Firm performance impacts of digitally enabled supply chain integration capabilities. MIS Q. 30(2):225-246.

[38] Raudenbush SW, Bryk AS. 2002. Hierarchical Linear Models in Social and Behavioral Research: Applications and Data-Analysis

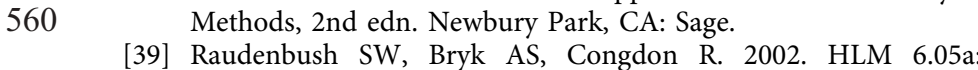
Hierarchical Linear and Nonlinear Modeling. Lincolnwood, IL: Scientific Software International.

[40] Robinson WS. 1950. Ecological correlations and the behavior of the individual. Am Sociol Rev. 15:351-357.

[41] Sambamurthy V, Zmud RW. 2000. Research commentary: The organizing logic for an enterprise's IT activities in the digital era A prognosis of practice and a call for research. Inf Syst Res. 11 (2):105-114.
[42] Schumpeter JA. 1934. The Theory of Economic Development: An Inquiry into Profits, Capital, Credit, Interest, and the Business Cycle, Vol. 55. Transaction Publishers.

[43] Short JC, Ketchen DJ, Palmer TB, Hult GTM. 2007. Firm, strategic group, and industry influences on performance. Strategic Manage J. 28(2):147-167.

[44] Stiroh K. 2002. Information technology and the productivity revival: What do the industry-level data say? Am Econ Rev. 92 (5):1559-1576.

[45] Tambe P, Hitt LM. 2012. The productivity of information technology investments: New evidence from IT labor data. Inf Syst Res. 23(3):599-617,845,847.

[46] Thorndike EL. 1939. On the fallacy of imputing the correlations found for groups to the individuals or smaller groups composing them. Am J Psychol. 52:122-124.

[47] Triplett J, Bosworth B. Baumol's disease has been cured: IT and multi-factor productivity in US services industries. In The New Economy and Beyond: Past, Present and Future, D.W. Jansen ed., Edward Elgar Press, 2002.
570

Q7 